\title{
Effects of disinfectant and biofilm on the corrosion of cast iron pipes in a reclaimed water distribution system
}

\author{
Haibo Wang, Chun $\mathrm{Hu}^{*}$, Xuexiang Hu, Min Yang, Jiuhui Qu \\ State Key Laboratory of Environmental Aquatic Chemistry, Research Center for Eco-Environmental Sciences, \\ Chinese Academy of Sciences, Beijing 10085, China
}

\section{A R T I C L E I N F O}

\section{Article history:}

Received 3 August 2011

Received in revised form

17 November 2011

Accepted 1 December 2011

Available online 20 December 2011

\section{Keywords:}

Biofilm

Chlorine

Corrosion

Reclaimed water distribution system

\begin{abstract}
A B S T R A C T
The effects of disinfection and biofilm on the corrosion of cast iron pipe in a model reclaimed water distribution system were studied using annular reactors (ARs). The corrosion scales formed under different conditions were characterized by X-ray diffraction (XRD), energy dispersive spectroscopy (EDS), and scanning electron microscopy (SEM), while the bacterial characteristics of biofilm on the surface were determined using several molecular methods. The corrosion scales from the ARs with chlorine included predominantly $\alpha$-FeOOH and $\mathrm{Fe}_{2} \mathrm{O}_{3}$, while $\mathrm{CaPO}_{3}(\mathrm{OH}) \cdot 2 \mathrm{H}_{2} \mathrm{O}$ and $\alpha$-FeOOH were the predominant phases after chloramines replaced chlorine. Studies of the consumption of chlorine and iron release indicated that the formation of dense oxide layers and biofilm inhibited iron corrosion, causing stable lower chlorine decay. It was verified that iron-oxidizing bacteria (IOB) such as Sediminibacterium sp., and iron-reducing bacteria (IRB) such as Shewanella sp., synergistically interacted with the corrosion product to prevent further corrosion. For the ARs without disinfection, $\alpha$-FeOOH was the predominant phase at the primary stage, while $\mathrm{CaCO}_{3}$ and $\alpha-\mathrm{FeOOH}$ were predominant with increasing time. The mixed corrosioninducing bacteria, including the IRB Shewanella sp., the IOB Sediminibacterium sp., and the sulfur-oxidizing bacteria (SOB) Limnobacter thioxidans strain, promoted iron corrosion by synergistic interactions in the primary period, while anaerobic IRB became the predominant corrosion bacteria, preventing further corrosion via the formation of protective layers.

(c) 2011 Elsevier Ltd. All rights reserved.
\end{abstract}

\section{Introduction}

Reclamation and reuse of wastewater is one of the most effective ways to alleviate water resource scarcity. Reclaimed water can serve many purposes, such as irrigation, supplementation of ground water and scenic environmental use (i.e., artificial ponds and fountains). Although the final reclaimed wastewater meets regulatory standards, the water may undergo substantial changes in quality during transport through the distribution system to the use point. In particular, when cast iron pipes are used in the reclaimed water distribution system (RWDS), internal corrosion scales can shed into the water as the time until use increases. These corrosion scales can adversely affect water quality during distribution, with consequences such as: (1) "red water" or "colored water" that is produced when iron is released from corrosion scales, (2) a high demand for chlorine, and (3) biofilm growth (Sarin et al., 2004a, b).

According to early reports, corrosion scales formed in old iron/steel drinking water distribution pipes were porous deposits with a layered structure (Sarin et al., 2001). Sarin et al. $(2004 \mathrm{a}, \mathrm{b})$ indicated that unlined iron corrosion scales include goethite $(\alpha-\mathrm{FeOOH})$, lepidocrocite $(\gamma-\mathrm{FeOOH})$, magnetite $\left(\mathrm{Fe}_{3} \mathrm{O}_{4}\right)$, ferrous hydroxide $\left(\mathrm{Fe}(\mathrm{OH})_{2}\right)$, ferric hydroxide $\left(\mathrm{Fe}(\mathrm{OH})_{3}\right)$,

\footnotetext{
* Corresponding author. Tel.: +8610 62849628; fax: +861062923541.

E-mail address: huchun@rcees.ac.cn (C. Hu). 
siderite $\left(\mathrm{FeCO}_{3}\right)$ and hematite $\left(\alpha-\mathrm{Fe}_{2} \mathrm{O}_{3}\right)$. In addition, other products were also observed in some corrosion scales, such as maghemite $\left(\gamma-\mathrm{Fe}_{2} \mathrm{O}_{3}\right)$, calcite $\left(\mathrm{CaCO}_{3}\right)$, quartz $\left(\mathrm{SiO}_{2}\right)$, troilite (FeS), domomite $\left(\mathrm{CaMg}\left(\mathrm{CO}_{3}\right)_{2}\right)$, hydroxyapatite $\left(\mathrm{Ca}_{5}\left(\mathrm{PO}_{4}\right)_{3} \mathrm{OH}\right)$, ferrihydrite $\left(5 \mathrm{Fe}_{2} \mathrm{O}_{3} \cdot 9 \mathrm{H}_{2} \mathrm{O}\right)$ and green rusts $\left(\mathrm{Fe}_{4}^{\mathrm{II}} \mathrm{Fe}_{2}^{\mathrm{III}}(\mathrm{OH})_{12}\left(\mathrm{CO}_{3}\right)\right)$ (Refait et al., 1998; Teng et al., 2008; Peng et al., 2010). There were different compositions of corrosion scales formed in different conditions.

Several reports have examined metal corrosion, including both electrochemical corrosion and microbiologically influenced corrosion (MIC). In addition, biofilm was reported to contribute to the formation of corrosion cells on metal surfaces due to the growth of microorganisms; i.e., biofilm comprises several bacterial genera that can accelerate metal corrosion (Lin et al., 2001; Starosvetsky et al., 2001). The majority of MIC investigations have addressed the impact of pure or mixed culture bacterial biofilm on corrosion behavior (Beech and Gaylarde, 1999). The main types of bacteria associated with metals in terrestrial and aquatic habitats are sulfate-reducing bacteria (SRB), sulfur-oxidizing bacteria (SOB), iron-oxidizing/reducing bacteria (IOB/IRB) and bacteria secreting organic acids and slime (Beech and Gaylarde, 1999; Beech, 2004; Teng et al., 2008). Biocorrosion is a result of interactions, which are often synergistic, between the metal surface, abiotic corrosion products, and bacterial cells and their metabolites (Beech and Sunner, 2004; Beech et al., 2005). The promotive effects of microbiological activities on electrochemical corrosion were proved in these studies. However, other reports suggest that biofilm can protect metal from corrosion under specific conditions (Zuo et al., 2005; Teng et al., 2008). The main mechanism of corrosion inhibition is developed at metal surfaces when the extracellular polymeric substances (EPS) of the biofilm impede the dissolution of $\mathrm{Fe}^{2+}$ corrosion products (Videla and Herrera, 2009). Herrera and Videla (2009) indicated the capacity of IRB in inhibiting corrosion. These findings contradict the common sense notion that microbes promote metal corrosion.

Recently, in water distribution system, disinfectant was used to control the bacteria regrowth. However, disinfectant can result in metal corrosion and bacteria in metal surface can inhibit or accelerate the metal corrosion. It is also widely accepted in the literature that disinfectant residuals increase corrosion rates (AWWA, 1999; McNeill and Edwards, 2001). Further, they pose the question: what are the effects of biofilm that are common in RWDS on the corrosion of cast iron pipes and what are the effects of disinfectant on biofilm and corrosion?

Therefore, the major objectives of this work were to investigate: (1) the effect of disinfectant and biofilm on the corrosion of cast iron coupons in an RWDS, (2) whether the biofilm in a RWDS promote or inhibit the corrosion of cast iron pipes, and (3) the elemental composition and crystalline phase of the corrosion scales in RWDS. In addition, the microbial communities of the biofilm on the cast iron coupons were characterized using polymerase chain reaction (PCR) and denaturing gradient gel electrophoresis (DGGE) analysis (Martiny et al., 2003; Emtiazi et al., 2004). Furthermore, a corrosion mechanism was proposed for different project periods on the basis of the characterization results for the structure of corrosion scales and the microbial communities of biofilm.

\section{Materials and methods}

\subsection{Model distribution system}

Annular reactors (ARs) (Model 1320LJ, BioSurface Technologies Corp., USA) were used to simulate reclaimed water distribution systems. The ARs consist of two concentric glass cylinders and a rotating inner drum that houses 20 flushmounted removable cast iron coupons. Each coupon has an exposed surface area of $17.5 \mathrm{~cm}^{2}$ for biofilm growth.

Two ARs were established in parallel and operated at a rotational speed of $50 \mathrm{rpm}$, which approximately corresponds to a shear stress of $0.25 \mathrm{~N} / \mathrm{m}^{2}$, a level consistent with previously published studies (Murphy et al., 2008). The hydraulic retention time (HRT) for the reactors was $6 \mathrm{~h}$, which translated into a total flow rate of $2.8 \mathrm{~mL} / \mathrm{min}$ into the ARs. All glass surfaces and any exposed surfaces were covered with aluminum foil to reduce the potential for phototrophic growth within the system.

\subsection{Analysis of water quality and corrosion scales}

Effluents and biofilm samples were taken from each AR weekly. The biofilms were collected from the coupon using a previously described method (Gagnon and Slawson, 1999). Iron bacteria and sulfate reducing bacteria (SRB) were analyzed using the most probable number (MPN) method (Varughese et al., 2007).

Water quality parameters, such as alkalinity, hardness, chloride ion $\left(\mathrm{Cl}^{-}\right)$, sulfate ion $\left(\mathrm{SO}_{4}^{2-}\right)$ and total dissolved solids (TDS) were measured according to the standard method (EPA of China, 2002). Chlorine was measured using N, N-diethyl-1, 4-phenylenediamine (DPD) method (EPA of China, 2002). Sodium hypochlorite solution was added to AR for 97 days, and then chloramine prepared by combining sodium hypochlorite and ammonium chloride was added to the AR instead of sodium hypochlorite for 60 days. Inductively coupled plasma mass spectrometers (ICP/MS) (Plasma Quad 3, VG, England) were used to analyze the total iron. And the concentration of ferrous ion was determined by hydroxylamine hydrochloride method according to the standard method (EPA of China, 2002). Dissolved organic carbon (DOC) was analyzed using a total organic carbon (TOC) analyzer (Pheonix 8000; Tekmer-Dohrmann, USA). Biodegradable dissolved organic carbon (BDOC) were measured according to the method of Escobar et al. (2001). Differences between water quality parameters were measured using an ANOVA method with a significance threshold of $\alpha=0.05$.

The elemental composition and morphologies of corrosion deposits were detected by scanning electron microscopy and energy dispersive spectroscopy (SEM/EDS) (S-3000N, HITACHI, Japan). Crystalline phase composition was analyzed using an X-ray powder diffractometer (X'Pert PRO MPD, PANalytical, the Netherlands).

\subsection{DNA extraction and PCR-DGGE}

The procedure included DNA extraction, PCR-DGGE, and sequence analysis (Pozos et al., 2004). 
DNA extraction was conducted using a FastDNA spin kit for soil. For the PCR-DGGE analysis, the whole length region of bacterial 16S rDNA was amplified with the universal primers 954f (5'-GCACAAGCGGTGGAGCATGTGG-3') and 1369r (5'GCCCGGGAACGTATTCACCG-3') (Araya et al., 2003). In addition, a GC clamp (5'-CGCCCGCCGCGCCCCGCGCCCGGCCCGC CGCCCCCGCCCC- $3^{\prime}$ ) was attached to the $5^{\prime}$-end of the forward primer for subsequent DGGE analysis.

Touchdown PCR was performed as follows: $94{ }^{\circ} \mathrm{C}$ for $10 \mathrm{~min}$, followed by 20 cycles of $94^{\circ} \mathrm{C}$ for $1 \mathrm{~min}, 65^{\circ} \mathrm{C}$ (reduced by $0.5^{\circ} \mathrm{C}$ each cycle) for $1 \mathrm{~min}$, and $72^{\circ} \mathrm{C}$ for $1 \mathrm{~min}, 10$ cycles of $94{ }^{\circ} \mathrm{C}$ for $1 \mathrm{~min}, 55^{\circ} \mathrm{C}$ for $1 \mathrm{~min}$, and $72^{\circ} \mathrm{C}$ for $1 \mathrm{~min}$. Finally, an extension step was carried out at $72^{\circ} \mathrm{C}$ for $8 \mathrm{~min}$.

DGGE analysis, based on the protocol described by Grommen et al. (2005), was performed using the Bio-Rad D Gene System (Bio-Rad, Hercules, USA). The PCR products were loaded onto $6 \%(\mathrm{w} / \mathrm{v})$ polyacrylamide gels in $1 \times \mathrm{TAE}$. The polyacrylamide gels were made with denaturing gradient ranging from $40 \%$ to $60 \%$. Electrophoresis was run for $6 \mathrm{~h}$ at $60{ }^{\circ} \mathrm{C}$ and $120 \mathrm{~V}$ after which the gels were stained for $30 \mathrm{~min}$ with EB and photographed.

The sequencing was done by an $\mathrm{ABI}$ automated sequencer (Invitrogen, Shanghai, China). Then, FASTA and BLAST DNA homology searches were performed with the NCBI DNA database software of the US National Institutes of Health, accessed on the internet at http://www.ncbi.nlm.nih.gov (Schwartz et al., 2003).

\section{Results and discussion}

\section{1. $\quad$ Reclaimed water quality}

Effluents collected from a water reclamation plant located in Northern China were immediately delivered to the laboratory and stored at $4{ }^{\circ} \mathrm{C}$. No significant changes occurred in the reclaimed water quality during the experiment. Table 1 shows that the concentrations of DOC, $\mathrm{Cl}^{-}$, and $\mathrm{SO}_{4}^{2-}$ were $6.0 \sim 7.6$, $162.3 \sim 272.8$ and $143.1 \sim 189.0 \mathrm{mg} / \mathrm{L}$, respectively, and the alkalinity and hardness were $107.8 \sim 144.2$ and $304.7 \sim 363.5 \mathrm{mg} \mathrm{CaCO}_{3} / \mathrm{L}$, respectively. It has been reported that bacteria could regrow when biodegradable dissolved

Table 1 - Main parameters of water samples used in the experiments.

\begin{tabular}{|c|c|}
\hline Parameter & Value \\
\hline $\mathrm{pH}$ & $6.9 \sim 8.0$ \\
\hline Turbidity (NTU) & $0.3 \sim 0.8$ \\
\hline Conductivity ( $\mu \mathrm{S} / \mathrm{cm})$ & $1176 \sim 1681$ \\
\hline TDS (mg/L) & $580 \sim 839$ \\
\hline Alkalinity $\left(\mathrm{mg} \mathrm{CaCO}_{3} / \mathrm{L}\right)$ & $107.8 \sim 144.2$ \\
\hline Hardness $\left(\mathrm{mg} \mathrm{CaCO}_{3} / \mathrm{L}\right)$ & $304.7 \sim 363.5$ \\
\hline Total iron $(\mathrm{mg} / \mathrm{L})$ & $0.027 \sim 0.060$ \\
\hline $\mathrm{Cl}^{-}(\mathrm{mg} / \mathrm{L})$ & $162.3 \sim 272.8$ \\
\hline $\mathrm{SO}_{4}^{2-}(\mathrm{mg} / \mathrm{L})$ & $143.1 \sim 189.0$ \\
\hline $\mathrm{DOC}(\mathrm{mg} / \mathrm{L})$ & $6.0 \sim 7.6$ \\
\hline $\mathrm{BDOC}(\mathrm{mg} / \mathrm{L})$ & $0.5 \sim 0.7$ \\
\hline LI & $3.28 \sim 4.05$ \\
\hline
\end{tabular}

organic carbon (BDOC) content in the water was more than $0.15 \mathrm{mg} / \mathrm{L}$ (Escobar et al., 2001). In the experiments, the concentration of $\mathrm{BDOC}$ in the reclaimed water was $0.5 \sim 0.7 \mathrm{mg} / \mathrm{L}$, which would result in bacteria regrowth. Meanwhile, a significant linear relationship between iron release and the Larson-Skold Index (LI) has been observed, and $\mathrm{LI}$ which is equal to $\left(\left[\mathrm{Cl}^{-}\right]+2\left[\mathrm{SO}_{4}^{2-}\right]\right) /\left[\mathrm{HCO}_{3}^{-}\right]$is used as a predictive measurement of iron corrosion (Melidis et al., 2007; Ishii and Boyer, 2011). High corrosion rates tended to result from waters with a LI $>1.2$. In this study, LI was calculated as $3.28 \sim 4.05$, which would facilitate corrosion of the cast iron pipes.

\subsection{Disinfectant and iron release}

Fig. 1 shows changes of the disinfectant content in the influents and effluents. The initial chlorine dose in the influents was $1.0 \mathrm{mg} / \mathrm{L}$, while the residual chlorine decreased from $0.64 \mathrm{mg} / \mathrm{L}$ to 0 within the 5 days. Until the initial chlorine dose in the influents was $40 \mathrm{mg} / \mathrm{L}$ at $\mathrm{d} 12$, the residual chlorine was $2.0 \mathrm{mg} / \mathrm{L}$. Then, from d 15 onward, the initial chlorine dose in the influents was controlled at $10 \mathrm{mg} / \mathrm{L}$ and the residual chlorine reached stable levels $(1.0 \mathrm{mg} / \mathrm{L})$ until d 97 . Subsequently, chloramine was added to the AR in place of sodium hypochlorite solution. The initial dose in influents was $14 \mathrm{mg} / \mathrm{L}$, and residual chlorine were $4.0 \mathrm{mg} / \mathrm{L}$.

In the initial stage, the chlorine was quickly decayed due to reacting with the metallic cast iron coupons (Eqs. (1) and (2)). With the formation of a dense oxide layer, the consumption of chlorine was decreased.

$$
\begin{aligned}
& 6 \mathrm{Fe}^{2+}+3 \mathrm{ClO}^{-}+3 \mathrm{H}_{2} \mathrm{O} \rightleftharpoons 2 \mathrm{Fe}(\mathrm{OH})_{3}+4 \mathrm{Fe}^{3+}+3 \mathrm{Cl}^{-} \\
& 2 \mathrm{Fe}^{2+}+\mathrm{HClO}+\mathrm{H}^{+} \rightleftharpoons 2 \mathrm{Fe}^{3+}+\mathrm{Cl}^{-}+\mathrm{H}_{2} \mathrm{O}
\end{aligned}
$$

During the experiment, the total iron in the average concentration of influents was approximately $0.04 \mathrm{mg} / \mathrm{L}$, and the total iron concentration of the effluents exhibited different changes in the ARs with and without chlorine. In AR with chlorine, the total iron concentration of the effluents was $1.1 \mathrm{mg} / \mathrm{L}$ (Fig. 2a) over the first 10 days, then it stabilized at approximately $0.25 \mathrm{mg} / \mathrm{L}$ with steady chlorine consumption.

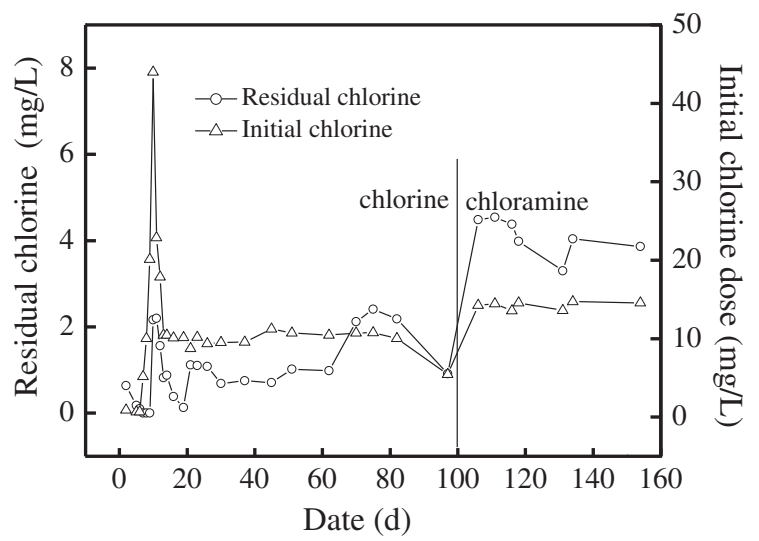

Fig. 1 - Changes in the chlorine concentration of effluents of the reactor with cast iron coupons when different concentrations of disinfectant were added. 
The iron content in the effluent decreased with increasing time, indicating that the iron corrosion rate greatly decreased with time. In addition, the total iron concentration in the effluents greatly decreased to $0.03 \mathrm{mg} / \mathrm{L}$ when high concentration of chloramines was added to the reactor.

In AR without chlorine, the total iron concentration in the effluents was $0.1 \mathrm{mg} / \mathrm{L}$ (Fig. $2 \mathrm{~b}$ ) within the first 30 days. Then, it increased significantly from $0.1 \mathrm{mg} / \mathrm{L}$ to $0.3 \mathrm{mg} / \mathrm{L}$ at $\mathrm{d} 70$. Subsequently, it decreased gradually and stabilized at approximately $0.05 \mathrm{mg} / \mathrm{L}$. The results indicated that the corrosion rate increased at primary stage and then decreased.

The statistical analysis revealed that there was a significant difference between the iron concentrations of influents and effluents ( $p=0.0003$ ) before d 20; after $\mathrm{d} 20$, when chlorine and chloramines were added, there was no longer a difference ( $p=0.0852$ ). This result supported the previous conclusions that chlorine accelerated the corrosion rate before $d 20$, after which the oxide layer prevented further corrosion. However, there were no significant differences in the concentrations of iron between influents and effluents $(p=0.086)$ in the ARs without disinfectant throughout the experiment.

\subsection{Structure and composition of the corrosion scales}

Fig. 3(a) shows the XRD patterns of the corrosion scales on iron coupons without disinfectant at different times. Goethite
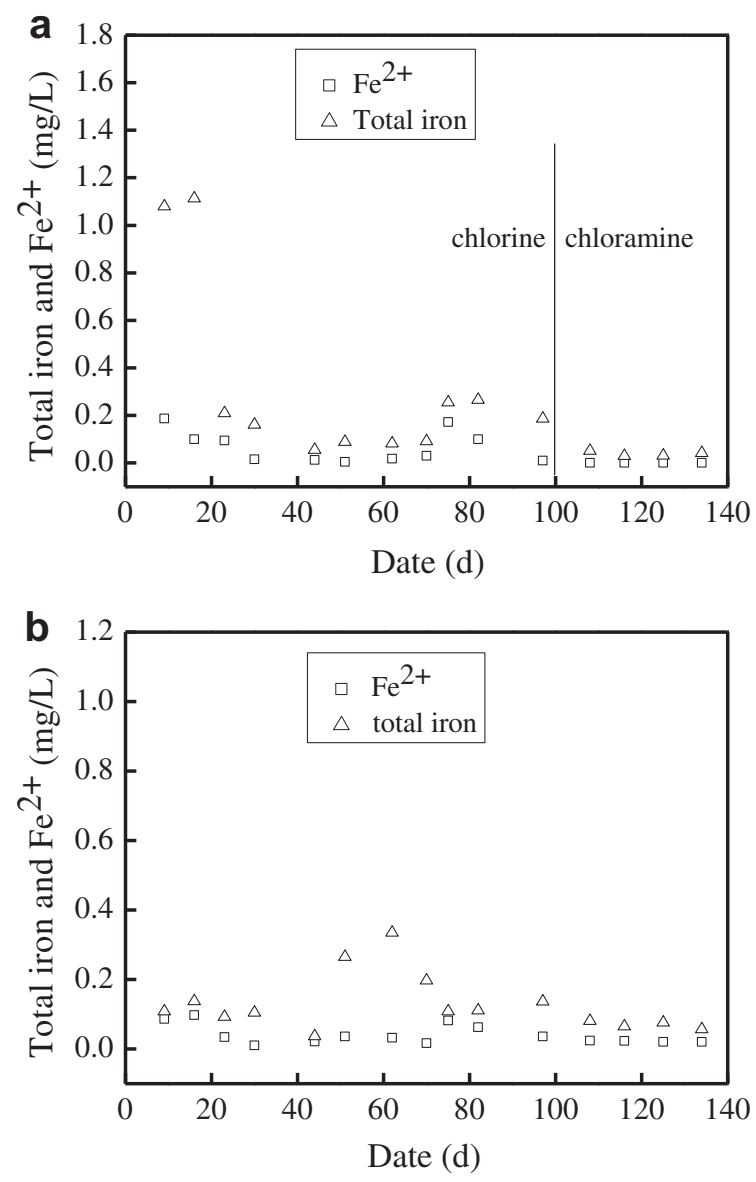

Fig. 2 - An analysis of the iron released from different reactors: (a) with disinfectant; (b) without disinfectant.
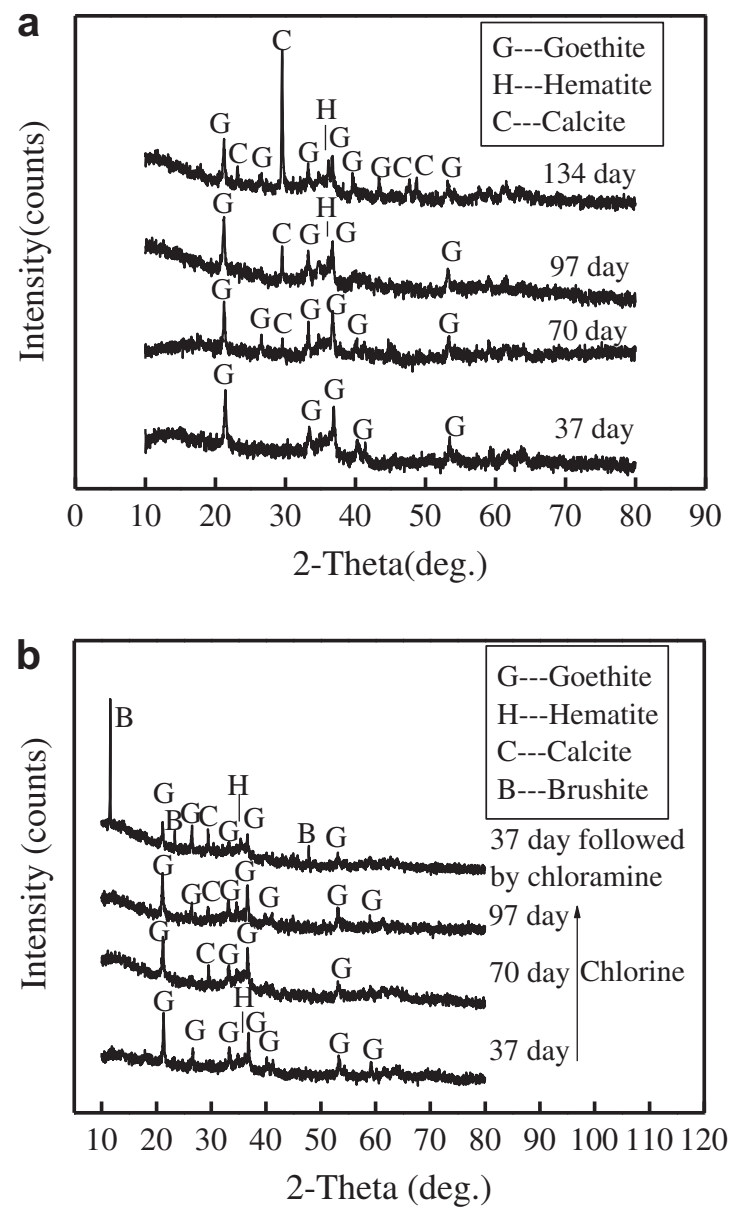

Fig. 3 - X-ray diffraction (XRD) patterns of the corrosion scales on iron pipes (a) without disinfectant; (b) with disinfectant.

$(\alpha-\mathrm{FeOOH})$ was observed in all samples. Only $\alpha$-FeOOH existed in the $d 37$ sample, while calcite $\left(\mathrm{CaCO}_{3}\right)$ was present in the d 70 sample in addition to the predominant $\alpha$-FeOOH phase. In addition to the two phases, hematite $\left(\mathrm{Fe}_{2} \mathrm{O}_{3}\right)$ was detected in the samples from d 97 and $d 134$. The intensity of the $\mathrm{CaCO}_{3}$ peaks increased from $\mathrm{d} 70$ to $\mathrm{d} 134$, and more peaks for $\mathrm{CaCO}_{3}$ appeared, indicating the crystalline growth of $\mathrm{CaCO}_{3}$. It is likely that $\mathrm{CaCO}_{3}$ also plays a role in reducing the iron release by decreasing the porosity of the scale. The XRD patterns of the corrosion scales on the iron coupons with disinfectant are presented in Fig. 3(b). $\alpha-\mathrm{FeOOH}, \mathrm{Fe}_{2} \mathrm{O}_{3}$, and $\mathrm{CaCO}_{3}$ were observed in all samples except for those taken before $d$ 37, which predominantly consisted of $\alpha$-FeOOH and $\mathrm{Fe}_{2} \mathrm{O}_{3}$. Moreover, with the addition of chloramines, a new crystalline phase brushite $\left(\mathrm{CaPO}_{3}(\mathrm{OH}) \cdot 2 \mathrm{H}_{2} \mathrm{O}\right)$ appeared. The formation of $\mathrm{Fe}_{2} \mathrm{O}_{3}$ was clearly enhanced by the addition of chlorine, which contributed to loss of $\mathrm{Fe}(\mathrm{OH})_{3}$. In the absence of disinfectants, the mean reaction followed equation (3), while equations (3) and (4) occurred with the addition of disinfectants.

$\mathrm{Fe}(\mathrm{OH})_{3} \rightleftharpoons \mathrm{FeOOH}+\mathrm{H}_{2} \mathrm{O}$

$2 \mathrm{Fe}(\mathrm{OH})_{3} \rightleftharpoons \mathrm{Fe}_{2} \mathrm{O}_{3}+3 \mathrm{H}_{2} \mathrm{O}$ 
Fig. 4 shows the SEM micrographs of the biofilm and corrosion scales on the cast iron coupons under different conditions. Without disinfectants, the corroded particles were agglomerated and loosely covered with bacteria cells. The corrosion scales exhibited extensive porosity, which decreased with time. In contrast, when chlorine was added, a dense oxide layer, which exhibited good crystalline particles, was formed by d 37 . However, by $d$ 70, the morphology of scale surfaces was loose, and numerous bacterial cells were present. After d 97, with the addition of chloramine, new crystals, which corresponded to $\mathrm{CaPO}_{3}(\mathrm{OH}) \cdot 2 \mathrm{H}_{2} \mathrm{O}$, had formed on the pipe surface. Furthermore, the elemental composition of the scales was determined by SEM/EDS measurements (Table 2). The iron content of the scales formed with chlorine was 63.76 wt\%, which changed to $44.29 \mathrm{wt} \%$ with the addition of chloramines. The iron release at this point was zero (Fig. 2a), indicating that $\mathrm{CaPO}_{3}(\mathrm{OH})$. $2 \mathrm{H}_{2} \mathrm{O}$ greatly suppressed the transfer of iron at the water-solid interface. The iron content in the scales formed without disinfection was 53.93, 50.06, and 48.79 wt\% on $\mathrm{d} 37$, 97 , and 134, respectively, which was in agreement with the iron release, indicating that iron corrosion was depressed by the corrosion layer and biofilm.

\subsection{Bacterial counts in the biofilms}

Fig. 5 shows iron bacteria and sulfate-reducing bacteria (SRB) counts of the biofilm on the cast iron coupons under different conditions. The counts of iron bacteria were almost the same with and without chlorine from d 16 to 70 . However, after $d 70$, the water with added chlorine showed decreasing iron bacteria counts to levels lower than those measured under chlorine-free conditions. Furthermore, a significant reduction was observed on d 97, when chloramines were used; the iron bacteria counts decreased to 2.96 log from $4.66 \mathrm{log}$.

The corrosion rate decreased after $\mathrm{d} 70$ in the presence of chlorine or chloramines, as determined by XRD and SEM/EDS measurements. These results suggested that iron corrosion strongly enhanced the growth of iron bacteria within the biofilm, whereas disinfection had little effect on the growth. Without disinfection, the SRB counts of the biofilm did not significantly change throughout the experiment. However, with the addition of chlorine before $d 23$, the SRB count of the biofilm was $0.76 \mathrm{log}$, which increased to $1.41 \mathrm{log}$ at $\mathrm{d}$ 97, then greatly decreased to $0.63 \mathrm{log}$ when chloramines were added. These results indicated that the growth of SRB was not as dependant as that of iron bacteria on iron corrosion.

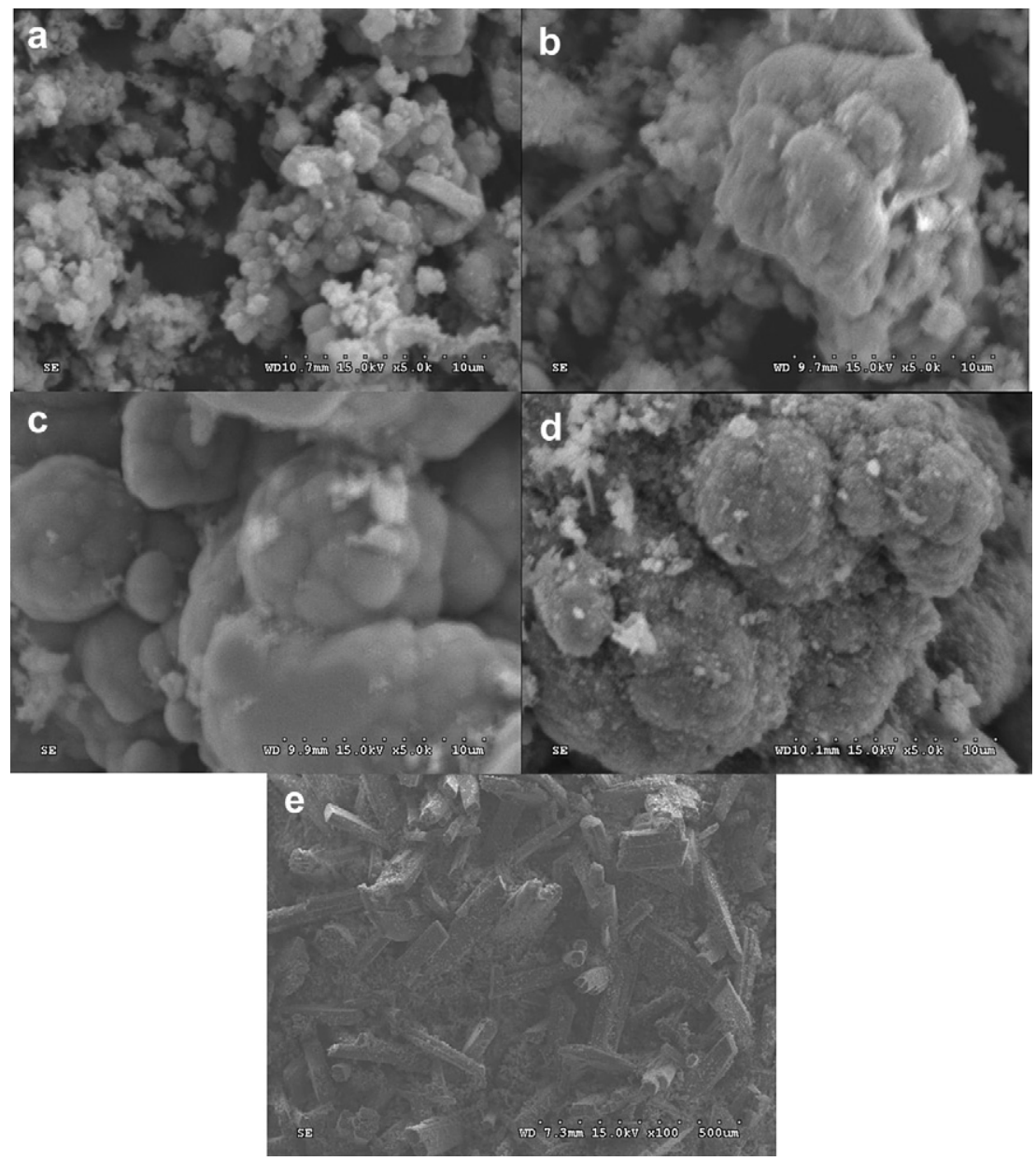

Fig. 4 - Scanning electron microscopy (SEM) micrographs of the biofilm formed on cast iron coupons at (a), (b) 37 and 70 days without disinfectant; (c), (d) 37 and 70 days with chlorine; and (e) 37 days followed by chloramine. 
Table 2 - The elemental composition ratio of corrosion scales on different days by SEM/EDS measurement.

\begin{tabular}{|c|c|c|c|c|c|c|}
\hline \multirow[t]{3}{*}{ Element } & \multicolumn{3}{|c|}{ Weight\% } & \multicolumn{3}{|c|}{ Weight\% } \\
\hline & \multicolumn{2}{|c|}{ Chlorine } & \multirow{2}{*}{$\frac{\text { Chloramine }}{37 \mathrm{~d}}$} & \multicolumn{3}{|c|}{ Without chlorine } \\
\hline & $37 \mathrm{~d}$ & $97 \mathrm{~d}$ & & $37 \mathrm{~d}$ & $97 \mathrm{~d}$ & $134 d$ \\
\hline $\mathrm{C}$ & 4.57 & 6.10 & 9.88 & 6.62 & 7.27 & 7.95 \\
\hline $\mathrm{O}$ & 20.08 & 17.03 & 20.16 & 23.35 & 24.66 & 23.97 \\
\hline$P$ & 1.66 & 0.23 & 5.51 & 2.05 & 1.60 & 1.75 \\
\hline $\mathrm{Ca}$ & 0.93 & 1.14 & 5.09 & 0.43 & 1.68 & 3.85 \\
\hline $\mathrm{Fe}$ & 63.76 & 63.05 & 44.29 & 53.93 & 50.06 & 48.79 \\
\hline Others & 9.00 & 12.45 & 15.07 & 13.62 & 14.73 & 13.69 \\
\hline
\end{tabular}

\subsection{Corrosion and bacterial characteristics of waters and biofilms}

The bacterial community compositions of the reclaimed waters and biofilms on different days and under different disinfectant levels were identified by PCR-DGGE (Fig. 6). Sequence analysis indicated that the majority of these samples represented the phylum Proteobacteria, and mostly comprised the classes Alphaproteobacteria, Betaproteobacteria, Gammaproteobacteria, and Deltaproteobacteria, followed by the phyla Bacteroidetes and uncultured bacterium (Table 3).

Several bacterial genera were observed in the influents, including the iron-oxidizing bacteria (IOB) Sediminibacterium

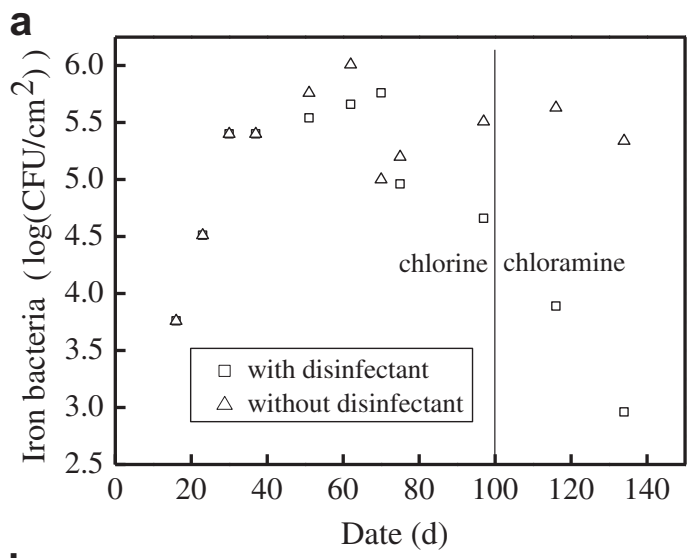

b

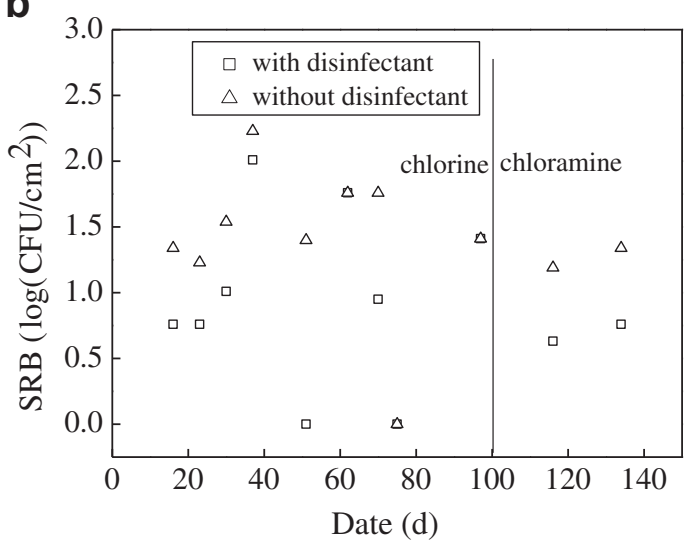

Fig. 5 - Iron bacteria (a) and sulfate reducing bacteria (SRB) (b) of the biofilms in different reactors.

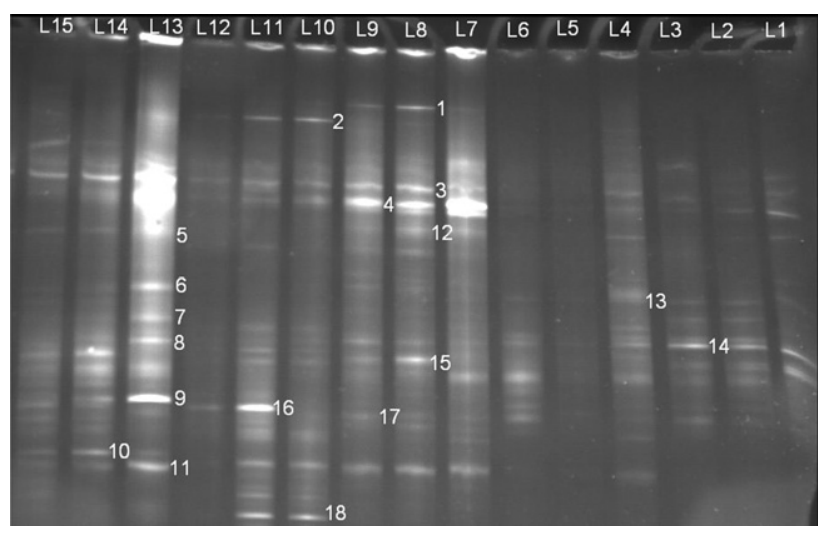

Fig. 6 - Denaturing gradient gel (DGGE) band pattern of waters and biofilms (without disinfectant at $d 56,76$, and 140: L1, L2, L3, influents; L7, L8, L9 effluents; L13, L14, L15 biofilms; with disinfectant: L4, L5, effluents of $d 56$ and 76 with chlorine; L6, effluents of $d \mathbf{4 3}$ followed by chloramine; L10, L11, biofilms of $d 56$ and 76 with chlorine, L12, bioflim of $d \mathbf{4 3}$ followed by chloramine).

sp. (band 4) (Qu and Yuan, 2008), the iron-reducing bacteria (IRB) Shewanella putrefaciens strain (band 3) (Herrera and Videla, 2009), and other heterotrophic bacteria (bands 13, 14) (Fgaier et al., 2008). Moreover, the microbe content of the influents did not change significantly throughout the experiment. The same bacteria were found in the effluents from the AR without disinfectant on d 56, 76, and 140. However, a significant increase in microbe diversity and biomass was observed in the effluents compared to the influents. These included the IOB Sediminibacterium sp. (band 4), the IRB Shewanella sp. (bands 3, 11), the sulfur-oxidizing bacteria (SOB) Limnobacter thioxidans strain (band 17) (Satoh et al., 2009), and other heterotrophic bacteria (bands 1, 12, 15). Band 4 was more intense than band 3 , indicating that the biomass of IOB was greater than that of IRB. On the other hand, the sulfur-oxidizing bacteria (SOB) Limnobacter thioxidans strain is also capable of converting ferrous sulfide to sulfuric acid, releasing ferrous iron in the process, which in turn could be used by the IOB Sediminibacterium sp. These results suggest that the iron oxidation reaction was predominant in the bulk of the water due to induction of IOB and SOB. Therefore, the ferric concentration was substantially higher than the ferrous concentration from d 23, when the biofilm was stable in the system (Fig. 2b). Furthermore, evidence of additional IRB (bands 3, 6, 8, 11), IOB (band 4), and SOB (band 17) was observed in the biofilm of $d 56$. Specifically, the bands were more intense and the diversity of microbes was greater. Conversely, the intensity and diversity of microbes were significantly reduced in the two samples collected on $\mathrm{d} 76$ and 140 . These bands, which were related to IRB, were more intense than band 4 of the IOB from $d 76$ to 140 . These results indicated that the biocorrosion mechanism was different between different corrosion periods (Beech and Sunner, 2004). During the primary stage of corrosion before $d 56$, these mixed corrosion-inducing bacteria (SRB/SOB and IRB/IOB) promoted iron corrosion via synergistic interactions between the metal surface and abiotic corrosion as well as the 
Table 3 - Sequencing results of bacteria of the model reclaimed water distribution system with cast iron coupons.

\begin{tabular}{llclc} 
Band & Closest relative in Genbank & Similarity (\%) & Bacterial group & Genbank number \\
\hline 1 & Uncultured bacterium clone & 93 & Uncultured bacterium & GQ379388 \\
2 & Flavobacteria bacterium KF030 gene & 99 & Bacteroidetes & AB269814 \\
3 & Shewanella putrefaciens strain ZH30 & 94 & Gammaproteobacteria & HM103350 \\
4 & Sediminibacterium sp. TEGAF015 & 99 & Bacteroidetes & AB470450 \\
5 & Pseudomonas sp. HI-B10 & 97 & Gammaproteobacteria & DQ196474 \\
6 & Shewanella algae strain UDC323 & 91 & Gammaproteobacteria & GQ245912 \\
7 & Pseudomonas sp. BWDY-1 & 97 & Gammaproteobacteria & DQ200850 \\
8 & Shewanella sp. 184 & 94 & Gammaproteobacteria & AF387349 \\
9 & Pseudomonas mendocina strain FB8 & 99 & Gammaproteobacteria & EU085557 \\
10 & Aeromonas aquariorum strain MDC47 & 100 & Gammaproteobacteria & HM103350 \\
11 & Shewanella putrefaciens strain ZH30 & 96 & Alphaproteobacteria & EU131006 \\
12 & Sphingomonas sp. BAC84 & 94 & Deltaproteobacteria & AJ288899 \\
13 & Bdellovibrio stolpii & 98 & Gammaproteobacteria & AB193724 \\
14 & Methylophilus methylotrophus gene & 99 & Betaproteobacteria & EU037269 \\
15 & Rheinheimera sp. G2DM-88 & 99 & Betaproteobacteria & HQ857618 \\
16 & Acidovorax sp. clone & 100 & Gammaproteobacteria & GQ284439 \\
17 & Limnobacter thioxidans strain & 100 & AJ519988 \\
18 & Thermomonas fusca & 99 & & \\
\hline
\end{tabular}

bacterial cells and their metabolities. On $\mathrm{d} 76$ and 140, the formation of corrosion layers and the biofilm decreased as iron and dissolved oxygen were released, resulting in the inhibition of $\mathrm{SRB} / \mathrm{SOB}$ and $\mathrm{IRB} / \mathrm{IOB}$ respiration and thereby reducing the biomass. In particular, the reduction of aerobic SOB and IOB suggested anoxic ecological niches of microbes at the water-solid interface. Anaerobic IRB became the main corrosion bacteria. IRB switched to ferric anaerobic respiration and the produced ferrous iron diffused into the bulk water, creating a chemical shield that reduced any oxygen diffusion. Ferrous iron was then oxidized to ferric iron and again reduced by bacterial respiration; corrosion was thereby inhibited.

In the AR with disinfectant, the DGGE bands of the effluents was less than that in the AR without disinfectant (Fig. 6), indicating that the chlorine and chloramines significantly decreased the microbe diversity, although several IOB and IRB remained. These were still apparent in the biofilm formed in the same system; however, SOB were not found and other heterotrophic bacteria were significantly decreased. The results indicated that there were different corrosion mechanisms in the ARs with and without disinfection. On $d 56$, the biofilm of the ARs with chlorine contained the IOB Sediminibacterium sp. (band 4), the IRBs Shewanella sp. (bands 3, 8, 11) and Thermomonas fusca (band 18) (Herrera and Videla, 2009). Thus, the diversity of corrosion bacteria had increased by $d 76$. The IOBs Sediminibacterium sp. (band 4) and Acidovorax sp. clone (band 16) (Casanova et al., 2010), as well as the IRBs Shewanella sp. (band 3, 8,11 ) and T. fusca (band 18) were observed, exhibiting comparable intensities, on $d 56$ and 76 with the addition of chlorine. The biomass of the biofilm drastically decreased following the addition of chloramines on d 43 (L12); the iron bacteria remained, although their intensity decreased. These results suggest that electrochemical corrosion and biocorrosion are involved in systems with disinfectant. During the primary stage (before d 56), electrochemical corrosion was predominant due to reduced biomass of corrosion bacteria. Corrosion of iron involves the formation of ferrous ion from iron metal (Eq. (5)) (Sarin et al., 2004a, b).
$\mathrm{Fe} \rightleftharpoons \mathrm{Fe}^{2+}+2 \mathrm{e}$

Electron acceptors such as oxygen, chlorine, or hydrogen ions in aqueous solution serve to complete the reaction. In near neutral $\mathrm{pH}$ water, when dissolved oxygen (DO) is present, the reduction of oxygen is the predominant cathodic reaction (Eq. (6)).

$\mathrm{O}_{2}+2 \mathrm{H}_{2} \mathrm{O}+4 \mathrm{e} \rightleftharpoons 4 \mathrm{OH}^{-}$

Meanwhile, aqueous chlorine species such as $\mathrm{HOCl}$ and $\mathrm{NH}_{2} \mathrm{Cl}$, which are used as disinfectants, also functioned as efficient electron acceptors, and thus promote the corrosion rate. Therefore, when chloramines were used in place of chlorine on $d 97$, the biomass of the corrosion bacteria was significantly reduced, leading to less biocorrosion. Electrochemical corrosion was predominant during this period, resulting in the formation of brushite. In contrast, from $d 56$ to $\mathrm{d} 97$, the iron corrosion bacteria (IOB/IRB) played predominant roles due to their large biomass and diversity. In the XRD patterns of the corrosion scales, the peaks representing $\alpha$ $\mathrm{FeOOH}$ (at $26.64^{\circ} 2 \theta$ and $59.12^{\circ} 2 \theta$ ) disappeared by $d 70$, then reappeared on $d 97$ (Fig. 3b). The intensities of the other peaks for $\alpha-\mathrm{FeOOH}$ on $\mathrm{d} 70$ were lower than those on $\mathrm{d} 37$. Moreover, significant numbers of bacterial cells were observed on the scale surfaces on $d 70$, and the top surface layer became loose (Fig. 4), suggesting the presence of amorphous $\alpha-\mathrm{FeOOH}$. Given that dense corrosion scales were formed with chlorine, the corrosion bacteria could not have interacted directly with the metal surface. These results verified that IRB/IOB interacted with the corrosion product, leading to the destruction of old $\alpha$ $\mathrm{FeOOH}$ and its reformation. In the process, IRB such as Shewanella can dissolve protective ferric oxides to extract the iron necessary for their Fe-dependent anaerobic respiration, which leads to the breakdown of passive ferric oxide layers. However, the resulting ferrous iron is oxidized to ferric iron to reform $\alpha-\mathrm{FeOOH}$ via the respiration role of IOB, which was confirmed by the increased biomass and diversity of IOB on d 76. Therefore, iron corrosion was depressed by the synergetic interaction between IRB/IOB and the corrosion product. 


\section{Conclusions}

Our results verified that both disinfectants and biofilm can substantially affect iron corrosion as well as the structure, composition, and morphology of corrosion scales. With respect to the composition of corrosion scales, in the absence of disinfectant, $\alpha$-FeOOH was the predominant phase before d 97, while $\mathrm{CaCO}_{3}$ and $\alpha-\mathrm{FeOOH}$ were predominant after $\mathrm{d}$ 97, given the different corrosion mechanisms of the ironcorroding bacteria. Furthermore, under the same conditions, the biofilm bacteria that formed on the corrosion scales were identified as the IRB Shewanella sp., the IOB Sediminibacterium sp., and the SOB Limnobacter thioxidans strain. During the primary period, this mix of corrosion-inducing bacteria promoted iron corrosion via synergistic interactions between the metal surface and abiotic corrosion, as well as the bacterial cells and their metabolites. With the formation of protective layers, the biomass and diversity of corrosion bacteria decreased, while anaerobic IRB became the predominant corrosion bacteria, preventing further corrosion from occurring. In the presence of chlorine, $\alpha-\mathrm{FeOOH}$ and $\mathrm{Fe}_{2} \mathrm{O}_{3}$ comprised the predominant phase in the corrosion scales, while $\mathrm{CaPO}_{3}(\mathrm{OH}) \cdot 2 \mathrm{H}_{2} \mathrm{O}$ and $\alpha$-FeOOH were predominant in the corrosion scales after chloramines replaced chlorine on $d$ 97. These corrosion scales greatly contributed to electrochemical corrosion. On $\mathrm{d} 70$ with chlorine, a loose top surface layer and bacteria cells were observed on the surface of the corrosion scales, suggesting the role of corrosion bacteria. Furthermore, the corrosion bacteria within the biofilm on the corrosion scales were identified as the IOB Sediminibacterium sp. and Acidovorax sp. clone, and the IRBs Shewanella sp. and $\mathrm{T}$. fusca. The synergistic interaction between the IRB and IOB with the corrosion product inhibited further corrosion.

\section{Acknowledgments}

This work was funded by the National Natural Science Foundation of China (No. 21125731, 50921064) and the Federal Department of Chinese Water Control and Treatment (No. 2008ZX07314-003, 2009ZX07424-003).

\section{R E F E R E N C E S}

Araya, R., Tani, K., Takagi, T., Yamaguchi, N., Nasu, M., 2003. Bacterial activity and community composition in stream water and biofilm from an urban river determined by fluorescent in situ hybridization and DGGE analysis. FEMS Microbiology Ecology 43 (1), 111-119.

AWWA, 1999. Water Quality and Treatment, fifth ed. McGrawHill, New York.

Beech, I.B., 2004. Corrosion of technical materials in the presence of biofilms-current understanding and state-of-the art methods of study. International Biodeterioration and Biodegradation 53 (3), 177-183.

Beech, I.B., Gaylarde, C.C., 1999. Recent advances in the study of biocorrosion-an overview. Revista de Microbiologia 30 (3), 177-190.
Beech, I.B., Sunner, J., 2004. Biocorrosion: towards understanding interactions between biofilms and metals. Current Opinion in Biotechnology 15 (3), 181-186.

Beech, I.B., Sunner, J.A., Hiraoka, K., 2005. Microbe-surface interactions in biofouling and biocorrosion processes. International Microbiology 8 (3), 157-168.

Casanova, P.L., Haderlein, S.B., Kappler, A., 2010. Biomineralization of lepidocrocite and goethite by nitratereducing $\mathrm{Fe}(\mathrm{II})$-oxidizing bacteria: effect of $\mathrm{pH}$, bicarbonate, phosphate, and humic acids. Geochimica et Cosmochimica Acta 74 (13), 3721-3734.

Emtiazi, F., Schwartz, T., Marten, S.M., Sidenstein, P.K., Obst, U., 2004. Investigation of natural biofilms formed during the production of drinking water from surface water embankment filtration. Water Research 38 (5), 1197-1206.

EPA of China, 2002. Analysis Method for Water and Waster Water, fourth ed. Press of Chinese Environmental Science.

Escobar, I.C., Randall, A.A., Taylor, J.S., 2001. Bacterial growth in distribution systems: effect of assimilable organic carbon and biodegradable dissolved organic carbon. Environmental Science and Technology 35 (17), 3442-3447.

Fgaier, H., Feher, B., McKellar, R.C., Eberl, H.J., 2008. Predictive modeling of siderophore production by Pseudomonas fluorescens under iron limitation. Journal of Theoretical Biology 251 (2), 348-362.

Gagnon, G.A., Slawson, R.M., 1999. An efficient biofilm removal method for bacterial cells exposed to drinking water. Journal of Microbiological Method 34 (3), 203-214.

Grommen, R., Dauw, L., Verstraete, W., 2005. Elevated salinity selects for a less diverse ammonia-oxidizing population in aquarium biofilters. FEMS Microbiology Ecology 52 (1), 1-11.

Herrera, L.K., Videla, H., 2009. Role of iron-reducing bacteria in corrosion and protection of carbon steel. International Biodeterioration and Biodegradation 63 (7), 891-905.

Ishii, S.K.L., Boyer, T.H., 2011. Evaluating the secondary effects of magnetic ion exchange: focus on corrosion potential in the distribution system. Desalination 274 (1-3), 31-38.

Lin, J.P., Ellaway, M., Adrien, R., 2001. Study of corrosion material accumulated on the inner wall of steel water pipe. Corrosion Science 43 (11), 2065-2081.

Martiny, A.C., Jorgensen, T.M., Albrechtsen, H.J., Arvin, E., Molin, S., 2003. Long-term succession of structure and diversity of a biofilm formed in a model drinking water distribution system. Applied and Environmental Microbiolog 69 (11), 6899-6907.

McNeill, L.S., Edwards, M., 2001. Iron pipe corrosion in distribution systems. Journal of American Water Works Association 93 (7), 88-100.

Melidis, P., Sanozidou, M., Mandusa, A., Ouzounis, K., 2007. Corrosion control by using indirect methods. Desalination 213 (1-3), 152-158.

Murphy, H.M., Payne, S.J., Gagnon, G.A., 2008. Sequential UVand chlorine-based disinfection to mitigate Escherichia coli in drinking water biofilms. Water Research 42 (8-9), 2083-2092.

Peng, C.Y., Korshin, G.V., Vslentine, R.L., Hill, A.S., 2010. Characterization of elemental and structural composition of corrosion scales and deposits formed in drinking water distribution systems. Water Research 44 (15), 4570-4580.

Pozos, N., Scow, K., Wuertz, S., Darby, J., 2004. UV disinfection in a model distribution system: biofilm growth and microbial community. Water Research 38 (13), 3083-3091.

Qu, J.H., Yuan, H.L., 2008. Sediminibacterium salmoneum gen. nov., sp. nov., a member of the phylum Bacteroidetes isolated from sediment of an eutrophic reservoir. International Journal of Systematic and Evolutionary Microbiology 58 (9), 2191-2194.

Refait, P., Abdelmoula, M., Génin, J.M., 1998. Mechanisms of formation and structure of green rust one in aqueous 
corrosion of iron in the presence of chloride ions. Corrosion Science 40 (9), 1547-1560.

Sarin, P., Snoeyink, V.L., Bebee, J., Jim, K.K., 2004a. Iron release from corroded iron pipes in drinking water distribution systems: effect of dissolved oxygen. Water Research 38 (5), 1259-1269.

Sarin, P., Snoeyink, V.L., Bebee, J., Kriven, W.M., Clement, J.A., 2001. Physico-chemical characteristics of corrosion scales in old iron pipes. Water Research 35 (12), 2961-2969.

Sarin, P., Snoeyink, V.L., Lytle, D.A., Kriven, W.M., 2004b. Iron corrosion scales: model for scale growth, iron release, and colored water formation. Journal of Environmental Engineering 130 (4), 364-373.

Satoh, H., Odagiri, M., Ito, T., Okabe, S., 2009. Microbial community structures and in situ sulfate-reducing and sulfur-oxidizing activities in biofilms developed on mortar specimens in a corroded sewer system. Water Research 43 (18), 4729-4739.

Schwartz, T., Kohnen, W., Jansen, B., Obst, U., 2003. Detection of antibiotic-resistant bacteria and their resistance genes in wastewater, surface water, and drinking water biofilms. FEMS Microbiology Ecology 43 (3), 325-335.
Starosvetsky, D., Armon, R., Yahalom, J., Starosvetsky, J., 2001. Pitting corrosion of carbon steel caused by iron bacteria. International Biodeterioration and Biodegradation 47 (2), 79-87.

Teng, F., Guan, Y.T., Zhu, W.P., 2008. Effect of biofilm on cast iron pipe corrosion in drinking water distribution system: corrosion scales characterization and microbial community structure investigation. Corrosion Science 50 (10), $2816-2823$.

Varughese, E.A., Wymer, L.J., Haugland, R.A., 2007. An integrated culture and real time PCR method to assess viability of disinfectant treated Bacillus spores using robotics and the MPN quantification method. Journal of Microbiological Method 71 (1), 66-70.

Videla, H.A., Herrera, L.K., 2009. Understanding microbial inhibition of corrosion. A comprehensive overview. International Biodeterioration and Biodegradation 63 (7), 896-906.

Zuo, R.J., Kus, E., Mansfeld, F., Wood, T.K., 2005. The importance of live biofilms in corrosion protection. Corrosion Science 47 (2), 279-287. 